\title{
Development and Validation of RP-HPLC Method for the Simultaneous Estimation of Haloperidol and Trihexy- phenidyl in API and Combined Tablet Dosage Form
}

\author{
E. Amulya ${ }^{1}$, N. Naveen Kumar ${ }^{2}$, CH. Mounika ${ }^{3}$, V. Kowmudi ${ }^{2}$, N. Supriya ${ }^{4}$, K. Ramya Madhuri ${ }^{2}$ \\ ${ }^{1}$ Dept. of Pharmaceutical Analysis and Quality Assurance, Ganga Pharmacy College, Telangana, India. \\ ${ }^{2}$ Dept. of Pharmaceutical Sciences, Ganga Pharmacy College, Telangana, India. \\ ${ }^{3}$ Dept. of Pharmaceutical Analysis and Quality Assuarance, Princeton College of Pharmacy, Telangana, India. \\ ${ }^{4}$ Dept. of Pharmaceutics, Samskruti College of Pharmacy, Telangana, India.
}

\section{ABSTRACT}

A rapid and precise reverse phase high performance liquid chromatographic method has been developed for the validated of Trihexyphenidyl and Haloperidol, in its pure form as well as in tablet dosage form. Chromatography was carried out on a Altima C18 $(4.6 \times 150 \mathrm{~mm}, 5 \mu \mathrm{m})$ column using a mixture of Methanol: TEA Buffer $\mathrm{pH}$ 4.5: Acetonitrile (50:25:25) as the mobile phase at a flow rate of $1.0 \mathrm{ml} / \mathrm{min}$, the detection was carried out at $225 \mathrm{~nm}$. The retention time of the Trihexyphenidyl and Haloperidol was 2.102, 3.537 $\pm 0.02 \mathrm{~min}$ respectively. The method produce linear responses in the concentration range of $15-75 \mathrm{ppm}$ of Trihexyphenidyland 37.5-187.5ppm of Haloperidol. The method precision for the determination of assay was below 2.0\%RSD. The method is useful in the quality control of pharmaceutical formulations.

Key words: trihexyphenidyl; haloperidol, RP-HPLC; validation; estimation

\section{INTRODUCTION}

Haloperidol is an antidyskinetic and antipsycotic drug whose IUPAC name is 1- cyclohexyl-1-phenyl-3-(1piperidyl)-1-propanol1. Molecular formula of Haloperidol is $\mathrm{C} 21 \mathrm{H} 23 \mathrm{ClFNO} 2$; the molecular weight is 375.864; the structural formula is shown below (GK Anthony et al., 2014).

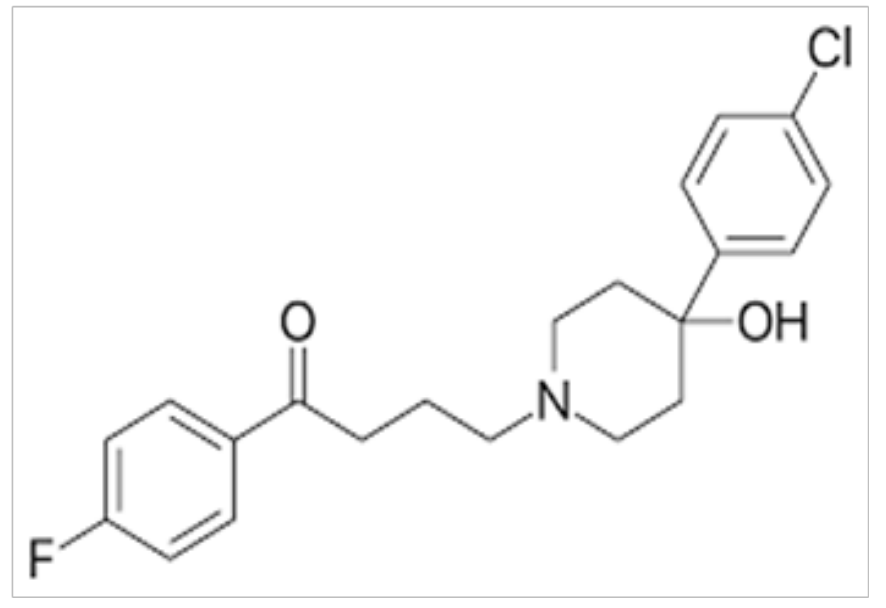

Fig. 1: Structure of Haloperidol
Trihexyphenidyl also known as benzhexol and trihex, is an antiparkinsonian, anticholinergic and antihistaminic drug. It is used for the symptomatic treatment of Parkinson's disease and to treat extrapyramidal side effects occurring during antipsychotic treatment. It reduces the frequency and duration of oculogyric crises as well as of dyskinetic movements and spastic contractions ( $P$. Subbareddy and TE Divakar, 2016).TrihexyphenidylHCl IUPAC name is 1-cyclohexyl-1-phenyl-3-(1-piperidyl) propan-1-ol hydrochloride (N Usha Rani et al., 2014) The molecular formula of $\mathrm{TXH}$ is $\mathrm{C} 20 \mathrm{H} 31 \mathrm{NO} . \mathrm{HCl}$; the

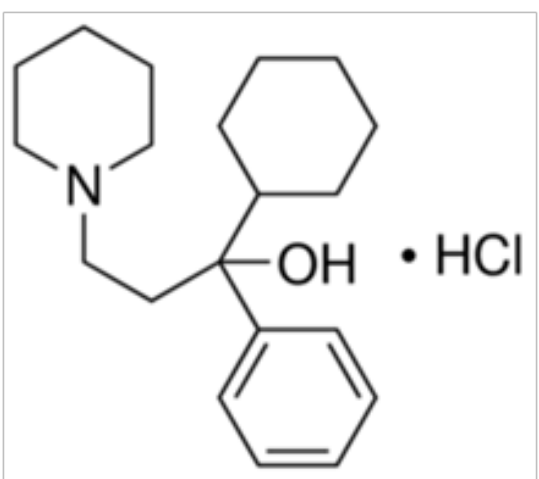

Fig. 2: Structure of Trihexyphenidyl

Corresponding author

E. Amulya

Email: amulyaeluka07@gmail.com

Received: 05-05-2018 
molecular weight is $337.93 \mathrm{~g} / \mathrm{mol}$; the structural formula is give below (Rudra Raju et al., 2014).

Several works are available for simultaneous estimation of Haloperidol and Trihexyphenidyl (Rudra Raju et al., 2014; AA Borkar et al., 2009). The aim of present work is to develop and validate a simple RP-HPLC method for simultaneous estimation of Haloperidol and Trihexyphenidyl.

\section{MATERIAL AND METHOD}

The drug samples Haloperidol and Trihexyphenidyl were obtained from Sura Labs., Hyderabad. The solvents used were of HPLC grade methanol and water from Merck Co, Mumbai.

\subsection{Intrumentation}

The HPLC system used was WATERS Alliance 2695 separation module, software: Empower 2, 996 PDA detector, Altima C18 $(4.6 \times 150 \mathrm{~mm}, 5 \mu)$ column.

\subsection{Chromatographic conditions}

Instrument used : Waters HPLC with auto sampler and PDA Detector 996 model.

Temperature $\quad: \quad 40^{\circ} \mathrm{C}$

Column : Altima C18 $(4.6 \times 150 \mathrm{~mm}, 5 \mu)$

Buffer : Dissolve $1.5 \mathrm{ml}$ of Ttiethyl amine in $250 \mathrm{ml}$ HPLC water and adjust the $\mathrm{pH}$ 4.5. Fliter and soni cate the solution by vaccum filtration and ultra sonication.

$\mathrm{pH} \quad: 4.5$

Mobile phase : Methanol: TEA buffer: ACN $(50: 25: 25 \mathrm{v} / \mathrm{v})$

Flow rate $\quad: 1 \mathrm{ml} / \mathrm{min}$

Wavelength : $225 \mathrm{~nm}$

Injection volume $\quad: \quad 10 \mu \mathrm{l}$

Run time : $7 \mathrm{~min}$

\subsection{Preparation of Buffer and Mobile Phase}

\subsubsection{Preparation of Triethylamine (TEA) buffer (pH-4.5)}

Dissolve $1.5 \mathrm{ml}$ of Ttiethyl amine in $250 \mathrm{ml}$ HPLC water and adjust the $\mathrm{p}^{\mathrm{H}} 4.5$. Fliter and sonicate the solution by vaccum filtration and ultrasonication.

\subsubsection{Preparation of mobile phase}

Accurately measured $400 \mathrm{ml}$ (40\%) of Methanol, $200 \mathrm{ml}$ of Triethylamine buffer (20\%) and $400 \mathrm{ml}$ of Acetonitrile $(40 \%)$ were mixed and degassed in digital ultrasonicater for 10 minutes and then filtered through $0.45 \mu$ filter under vacuum filtration.

\subsubsection{Diluent Preparation}

The Mobile phase was used as the diluent.

\subsubsection{Preparation of Standard Solution}

Accurately weigh and transfer $10 \mathrm{mg}$ of Trihexyphenidyl and $10 \mathrm{mg}$ of Haloperidol working standard into a $10 \mathrm{ml}$ of clean dry volumetric flasks add about $7 \mathrm{~mL}$ of Diluents and sonicate to dissolve it completely and make volume up to the mark with the same solvent. (Stock solution)

Further pipette $0.45 \mathrm{ml}$ of the above Trihexyphenidyl and $1.125 \mathrm{ml}$ of the Haloperidol stock solutions into a $10 \mathrm{ml}$ volumetric flask and dilute up to the mark with Diluent.

\subsubsection{Preparation of Sample Solution}

Take average weight of one Tablet and crush in a mortor by using pestle and weight $10 \mathrm{mg}$ equivalent weight of Trihexyphenidyl and Haloperidol sample into a $10 \mathrm{~mL}$ clean dry volumetric flask and add about $7 \mathrm{~mL}$ of Diluent and sonicate to dissolve it completely and make volume up to the mark with the same solvent.

Further pipette $1.125 \mathrm{ml}$ of the above sample stock solution into a $10 \mathrm{ml}$ volumetric flask and dilute up to the mark with Diluent.

\section{RESULTS AND DISCUSSION}

Method was validated according to ICH Guidelines in terms of linearity, range, accuracy, precision, limit of detection (LOD), and limit of quantitation (LOQ) (V. Tejasvi Reddy et al., 2016; K Ganesh et al., 2016).

\subsection{System Suitability}

The standard solution was injected for five times and measured the area for all five injections in HPLC. The \%RSD for the area of five replicate injections was found to be within the specified limits i.e., 1.09 for Trihexyphenidyl and 0.73 for Haloperidol.

\subsection{Linearity}

Linearity studies were done for five different concentrations of each drug. The five different concentrations covered 15-75 $\mu \mathrm{g} / \mathrm{ml}$ for Trihexyphenidyl and 37.5-187.5 $\mu \mathrm{g} / \mathrm{ml}$ for Haloperidol. 
The calibration curve showed good linearity in the range of $15-75 \mu \mathrm{g} / \mathrm{ml}$ with correlation coefficient (r2) of 0.999 and regression equation of $y=12066 x+13756$ for Trihexyphenidyl (Table 2). Calibration curve showed good linearity in the range of $37.5-187.5 \mu \mathrm{g} / \mathrm{ml}$ with correlation coefficient (r2) of 0.999 and regression equation of $y=18768 x+33265$ for Haloperidol (Table 2).

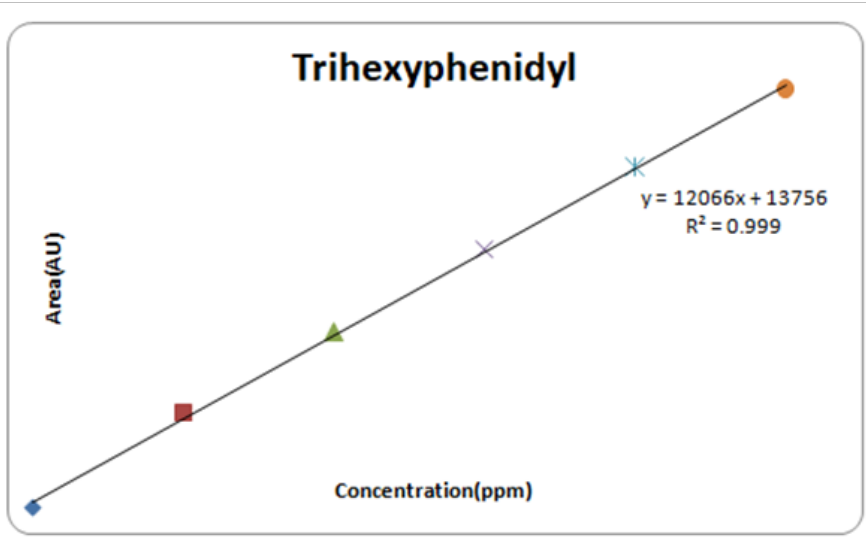

Fig.3: Calibration graph for Trihexyphenidyl

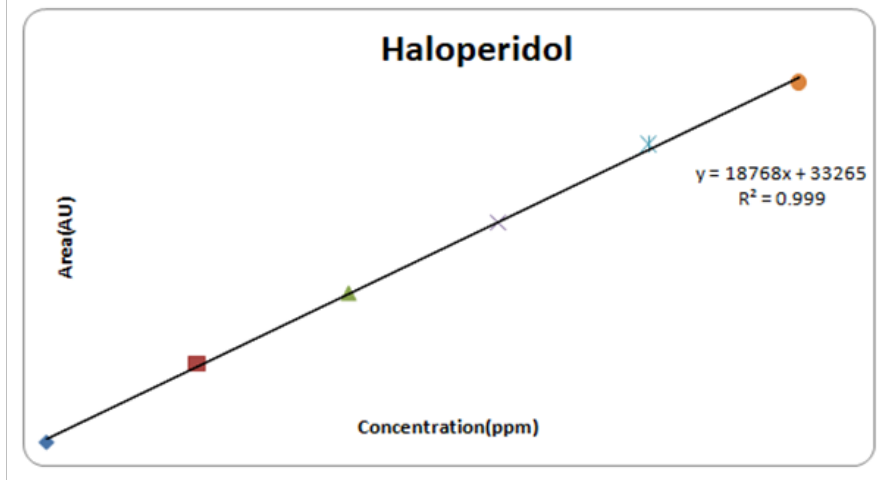

Fig. 4: Calibration graph for Haloperidol

\subsection{LOD and LOQ}

\subsubsection{Limit of detection}

The detection limit of an individual analytical procedure is the lowest amount of analyte in a sample which can be detected but not necessarily quantitated as an exact value.

$\mathrm{LOD}=3.3 \times \sigma / \mathrm{s}$

Where,

$\sigma=$ Standard deviation of the response

$\mathrm{S}=$ Slope of the calibration curve

\subsubsection{Limit of quantitation}

The quantitation limit of an individual analytical procedure is the lowest amount of analyte in a sample which can be quantitatively determined.

\section{$\mathrm{LOQ}=\mathbf{1 0 \times \sigma / \mathrm { S }}$}

Where,

$\sigma=$ Standard deviation of the response

$\mathrm{S}=$ Slope of the calibration curve

Table 1: Summary of validation parameters for the proposed method

\begin{tabular}{lll}
\hline Parameters & Trihexyphenidyl & Haloperidol \\
\hline Linearity & $15-75 \mu \mathrm{g} / \mathrm{ml}$ & $37.5-187.5 \mu \mathrm{g} / \mathrm{ml}$ \\
Intercept (c) & 13756 & 33265 \\
Slope $(\mathrm{m})$ & 12066 & 18768 \\
Correlation & 0.999 & 0.999 \\
coefficient & & \\
LOD & $0.8 \mu \mathrm{g} / \mathrm{ml}$ & $6.9 \mu \mathrm{g} / \mathrm{ml}$ \\
LOQ & $2.6 \mu \mathrm{g} / \mathrm{ml}$ & $21.1 \mu \mathrm{g} / \mathrm{ml}$ \\
\hline
\end{tabular}

\subsection{Precision}

\subsubsection{Repeatability}

The standard solution was injected for five times and measured the area for all five injections in HPLC. The \%RSD for the area of five replicate injections was found to be within the specified limits.

\subsubsection{Intermediate precision}

To evaluate the intermediate precision (also known as Ruggedness) of the method, Precision was performed on different days by maintaining same conditions. The $\%$ RSD for the area of six replicate injections was found to be within the specified limits.

\section{Acceptance criteria}

$\%$ RSD of Six different sample solutions should not more than 2

Table 2: Results of repeatability and intermediate precision of Trihexyphenidyl and Haloperidol

\begin{tabular}{lcccccc}
\hline Parameters & $\begin{array}{c}\text { Mean } \\
\text { Area }\end{array}$ & $\begin{array}{c}\text { Standard } \\
\text { Deviation }\end{array}$ & $\begin{array}{c}\% \\
R S D\end{array}$ & $\begin{array}{c}\text { Mean } \\
\text { Area } \\
\text { and SD } \\
(n=6)\end{array}$ & $\begin{array}{c}\text { Standard } \\
\text { Deviation }\end{array}$ & \\
\hline \multicolumn{7}{c}{ Trihexyphenidyl } \\
\hline Repeatability & 606665 & 2542.3 & 0.42 & 2217205 & 4100.8 & 0.18 \\
$\begin{array}{l}\text { Intermediate } \\
\text { precision }\end{array}$ & 596209 & 1718.7 & 0.29 & 2205575 & 2899.8 & 0.13 \\
\hline
\end{tabular}

\subsection{Accuracy}

To study accuracy of the proposed method, recovery studies were performed by spiking of standard drug solution to pre-analyzed sample at three different percentage concentrations $50,100,150 \%$. The resultant solutions were then reanalyzed by the proposed method. At each percentage concentration six determinations were 
Table 4: Results for robustness

\begin{tabular}{|c|c|c|c|c|c|}
\hline Drugs & $\begin{array}{l}\text { Parameter used for sample analy- } \\
\text { sis }\end{array}$ & Peak Area & Retention Time & $\begin{array}{c}\text { Theoretical } \\
\text { plates }\end{array}$ & Tailing factor \\
\hline \multirow{4}{*}{ Trihexyphenidyl } & Actual Flow rate of $1.0 \mathrm{~mL} / \mathrm{min}$ & 607323 & 2.102 & 5586 & 1.7 \\
\hline & Less Flow rate of $0.9 \mathrm{~mL} / \mathrm{min}$ & 674735 & 2.330 & 5231 & 1.7 \\
\hline & More Flow rate of $1.1 \mathrm{~mL} / \mathrm{min}$ & 1408920 & 1.950 & 5234 & 1.7 \\
\hline & Less organic phase & 606093 & 2.290 & 5643 & 1.4 \\
\hline \multirow{6}{*}{ Haloperidol } & More organic phase & 603559 & 1.998 & 5298 & 1.5 \\
\hline & Actual Flow rate of $1.0 \mathrm{~mL} / \mathrm{min}$ & 558777 & 3.537 & 5371 & 1.6 \\
\hline & Less Flow rate of $0.9 \mathrm{~mL} / \mathrm{min}$ & 2505636 & 3.885 & 5324 & 1.7 \\
\hline & More Flow rate of $1.1 \mathrm{~mL} / \mathrm{min}$ & 1408920 & 3.263 & 5098 & 1.7 \\
\hline & Less organic phase & 2239255 & 4.435 & 5239 & 1.2 \\
\hline & More organic phase & 2300346 & 3.009 & 5647 & 1.0 \\
\hline
\end{tabular}

performed. From the results obtained the method was found to be accurate. The percentage recovery and mean recovery were calculated and presented in table.

Table 3: Accuracy results for Trihexyphenidyl and Haloperidol

\begin{tabular}{lcccccc}
\hline \multicolumn{1}{c}{ Drug } & $\begin{array}{c}\text { \%Concentra- } \\
\text { tion } \\
\text { (at specifica- } \\
\text { tion Level) }\end{array}$ & Area & $\begin{array}{c}\text { Amount } \\
\text { Added } \\
\text { (ppm) }\end{array}$ & $\begin{array}{c}\text { Amount } \\
\text { Found } \\
\text { (ppm) }\end{array}$ & $\begin{array}{c}\text { \% Re- } \\
\text { covery }\end{array}$ & $\begin{array}{c}\text { Rean } \\
\text { Recovery }\end{array}$ \\
\hline $\begin{array}{l}\text { Trihexyphe- } \\
\text { nidyl }\end{array}$ & $50 \%$ & 287774 & 22.5 & 22.5 & 100 & \\
& $100 \%$ & 551495 & 45 & 44.8 & 98.6 & $99.6 \%$ \\
& $150 \%$ & 825175 & 67.5 & 67.42 & 99.5 & \\
Haloperidol & $50 \%$ & 1104782 & 56.25 & 56.249 & $100 \%$ & \\
& $100 \%$ & 2105321 & 112.5 & 112.48 & $99.9 \%$ & $100 \%$ \\
& $150 \%$ & 3211306 & 168.75 & 168.75 & $100 \%$ & \\
\hline
\end{tabular}

\subsection{Robustness}

Robustness of the method was determined by changing flow conditions and variation of mobile phase organic conditions. From the results obtained the method was found to be robust.

\section{Acceptance criteria}

The tailing factor should be less than 2.0 and the number of theoretical plates (N) should be more than 2000 .

\subsection{Formulation assay:}

The proposed RP-HPLC method was validated by simultaneously determining Trihexyphenidyl and Haloperidol in pharmaceutical dosage form. Inject the three replicate injections of standard and sample solutions and calculate the assay by using formula:

$$
\% \text { ASSAY }=
$$

Sample area Weight of standard Dilution of sample Purity Weight of tablet

Standard area Dilution of standard Weight of sample $100 \quad$ Label claim

The \% purity of Trihexyphenidyl and Haloperidol in pharmaceutical dosage form was found to be $99.6 \%$. and $99.7 \%$ respectively.

\section{CONCLUSION}

In the present investigation, a simple, sensitive, precise and accurate RP-HPLC method was developed for the quantitative estimation of Haloperidol and Trihexyphenidyl in bulk drug and pharmaceutical dosage forms. This method was simple, since diluted samples are directly used without any preliminary chemical derivatisation or purification steps. Haloperidol and Trihexyphenidyl was freely soluble in ethanol, methanol and sparingly soluble in water.

Methanol: TEA Buffer pH 4.5: Acetonitrile (50:25:25) was chosen as the mobile phase. The solvent system used in this method was economical. The \%RSD values were within 2 and the method was found to be precise.

\section{REFERENCES}

1. GK Anthony, Ramya Sri S (2014). Development and Validation of RP-HPLC method for simultaneous estimation of Risperidone and Haloperidol in tablet dosage forms. Int. J. Pharm. Drug. Anal. 2(9): 666-671.

2. K Ganesh, G Nikitha, D Sireesha, B Vasudha (2016). Development and validation of UV spectrophotometric method for simultaneous estimation of metformin and glipizide in tablet dosage form. Int. J. Appl. Pharm. Sci. Res. 1(2):56-59.

3. N Usha Rani, K Divya and G Sahithi (2014). New Validated RP-HPLC method for simultaneous estimation of chlorpromazine and TrihexyphenidylHcl in tablets. International Journal of Advances in Pharmaceutical Analysis. 4(4):134-137.

4. P.Subbareddy and TE Divakar (2016). Development and validation of a stability indicating RP-HPLC method for simultaneous estimation of Trihexyphenidyl and Trifluoperazine in pharmaceutical dosage forms. DER Pharmacia Lettre. 8(6):275-280. 
5. SP Wate and AA Borkar (2009). RP-HPLC estimation of Haloperidol and Trihexyphenidyl in tablets. International Journal of ChemTech Research. 1(3):675-676.

6. Srikanth Dammalapati, Ramesh Raju Rudra Raju (2014). A RP-HPLC method for simultaneous determination of Haloperidol and Trihexyphenidyl hydrochloride in tablet dosage form. Asian Journal of Pharmaceutical and Clinical Research. 7(2):14-18

7. V Tejasvi Reddy, S Hari Hara Kumar, M Akiful Haque, Dr. Vasudha Bakshi (2016). Method development and its validation for simultaneous estimation of domperidone and esome- prazole by RP-HPLC in combination tablet dosage form. Int. J. Appl. Pharm. Sci. Res. 1(1):46-55.

How to cite article: E. Amulya, N. Naveen Kumar, CH. Mounika, V. Kowmudi, N. Supriya, K. Ramya (2018). Development and validation of RP-HPLC method for the simultaneous estimation of haloperidol and trihexyphenidyl in API and combined tablet dosage form. Int. J. Appl. Pharm. Sci. Res. 3(3): 36-40 https://doi.org/10.21477/ijapsr.3.3.3

Source of Support; Nil Conflict of Interest: None declared 